\title{
At Home and Abroad
}




\section{RELIGION, CULTURE, AND PUBLIC LIFE}

Series Editor: Matthew Engelke

The Religion, Culture, and Public Life series is devoted to the study of religion in relation to social, cultural, and political dynamics, both contemporary and historical. It features work by scholars from a variety of disciplinary and methodological perspectives, including religious studies, anthropology, history, philosophy, political science, and sociology. The series is committed to deepening our critical understandings of the empirical and conceptual dimensions of religious thought and practice, as well as such related topics as secularism, pluralism, and political theology. The Religion, Culture, and Public Life series is sponsored by Columbia University's Institute for Religion, Culture, and Public Life.

For a complete list of titles, see page 355 . 


\title{
At Home and Abroad
}

\author{
The Politics of \\ American Religion
}

Edited by

Elizabeth Shakman Hurd

and Winnifred Fallers Sullivan

Columbia University Press

New York 
Publication of this book was made possible in part by funding from the Institute for Religion, Culture, and Public Life at Columbia University.

\author{
Columbia University Press \\ Publishers Since 1893 \\ New York Chichester, West Sussex \\ cup.columbia.edu \\ Copyright $\bigodot_{2021}$ Columbia University Press \\ All rights reserved
}

Library of Congress Cataloging-in-Publication Data

Names: Hurd, Elizabeth Shakman, 1970- editor. | Sullivan, Winnifred Fallers, 1950- editor.

Title: At home and abroad : the politics of American religion / edited by

Elizabeth Shakman Hurd and Winnifred Fallers Sullivan.

Description: New York : Columbia University Press, 2021. | Series: Religion,

culture, and public life | Includes bibliographical references and index.

Identifiers: LCCN 2020028011 (print) | LCCN 2020028012 (ebook) |

ISBN 978023119898I (hardback) | ISBN 9780231198998 (trade paperback) |

ISBN 9780231552905 (ebook)

Subjects: LCSH: Religion and politics-United States.

Classification: LCC BL2525.A88 202I (print) | LCC BL2525 (ebook) |

DDC 201/.720973-dc23

LC record available at https://lccn.loc.gov/20200280II

LC ebook record available at https://lccn.loc.gov/20200280I2

Columbia University Press books are printed

on permanent and durable acid-free paper.

Printed in the United States of America

Cover design: Milenda Nan Ok Lee 